\title{
The New Higher Education Reform and Higher Education Law in the "Social Dimension" Perspective: The Albanian Case
}

\author{
Elona Mehmeti \\ PhD candidate, Politican Science Department, Tirana University \\ Email:mehmetielona@gmail.com
}

\author{
Doi:10.5901/ajis.2015.v4n2s2p284
}

\section{Abstract}

\begin{abstract}
Higher education and research in Albania during these 24 years of democracy seems to be not in the international standards, progress seems to have been somewhat disappointing in the last 14 years of reforms in higher education. Although the number of universities and students enrolled in higher education has grown rapidly, the quality assurance remains an issue. For this reason the government is undertaking a reform that involves higher education which is expected to bring a dramatic change in the structure of the higher education and soon in the outputs. This new approach to higher education brought many debates among the stakeholders of higher education and especially among student's organizations. In this context this paper focus the analysis in particular of 1. 1) How the social dimension of higher education is perceived in the higher education reform and the new higher education law 2. What are the specific actions undertaken by the government to improve the participation of underrepresented groups in higher education. This paper and the study of the higher education reform and law is part of my $P h D$ thesis (which is in progress) which tends to open a discussion on the role that universities, as one of the main stakeholders of higher education, has in the Albanian society.
\end{abstract}

Keywords: Social dimension, Educational Reform. Higher education Law, European Higher Education

\section{Introduction}

The Social Dimension is a new concept, which seems to appear in European higher education and it was articulated clearly in the London bologna ministerial meeting in 2007.

Having a massive higher education and being aware of the fact that such a mass appeal leads to a greater heterogeneity of students, compared to the level of social, economic, cultural or race background "obligated" the countries to undertake further steps. In this context countries that singed the Bologna Agreement agreed that the diversity of students who entered higher education will not be an obstacle for the completion of their studies, therefore, countries that have signed the declaration take the commitment to facilitate any economic, social, cultural obstacle for students and assisted them in order to enable the completion of their studies .

However the commitment of the signatory countries yet, the social dimension remains a very general concept, as mentioned from Gwosć, Netz dhe Yagci the social dimension is a policy item that appeared into the Bologna Process agenda, but didn't transform itself into an implementable policy" (Orr, Gwosc', \& Netz, 2014; Yagci, 2014).

Despite that, the commitment of the countries remains very "Nobile", the main concern is how the reform is translated into the higher education reforms of each country as well as in the in the higher education law and development policies .

This short presentation has the purpose in focusing on the Albanian case as a country, which in 2003 signed the Bologna Agreement; it aims to show how the social dimension concept is translated into higher education reforms since 2007 and in the white paper 2014.

\section{What is the social dimension?}

According to the pear learning for the social dimension the concept of the social dimension of higher education was developed within the Bologna Process in the Prague Communique of 2001 and, it refers, to the objectives of removing inequalities in access to higher education in the European Area of Higher Education.

However the objective of the social dimension was mentioned clearly in the London Communiqué of 2007: where it is stated that: 
"We share the societal aspiration that the student body entering, participating in and completing higher education at all levels should reflect the diversity of our populations.

We reaffirm the importance of students being able to complete their studies without obstacles related to their social and economic background. We therefore continue our efforts to provide adequate student services, create more flexible learning pathways into and within higher education, and to widen participation at all levels on the basis of equal opportunity."

Having this fact in our mind, the social dimension takes into account that is three factors that tend to determine educational success:

- $\quad$ the student ability - material and immaterial (e.g. social and cultural) resources;

- the student opportunity, in particular, non-academic factors such as social background and aspirations for the future after graduation;

- the study conditions (e.g. balance between work and studies) that tend to affect participation and success in higher education.

The social dimension in this case indicated us to look at various stages of the higher education system and suggests measures that can help individuals to overcome difficulties and give the chance to students to participate and complete higher education.

\subsection{How it is "expressed" the concept of the social dimension "in the higher education law no. 9741 dated 21/05/2007 in} Albania

Higher education law of 2007 came as a need for a reconfiguration of the Albanian higher education landscape. The development and expansion of private and public higher education institutions, the significant increase in the number of students and as a result, the need for new academic staff, large-scale implementation of the European system of credits ECTS

Achievements of Higher Education Law no. 9741 dated 21.05.2007, according to E. Olldashi, and E. Koka in the Albanian higher education strategy were;

- The development of the internal and external Quality Assurance System for public and private universities (students must be included in all aspects of quality assurance)

- The establishment of curricula in public and private higher education institutions in the three cycles of studies following the Bologna scheme $3+2+3,4+1+3$ or $3+1$, which leads to Bachelor, Master and PhD degrees;

- To develop a social dimension in the higher education that related to economical support for the students in difficulty.

- To further develop democratic elections of governing bodies of the Higher Education Institutions and Student Governance Bodies in the decision-making process;

- The establishment of the new degree system based in the European Transferee Credit System commencing in the academic year 2006-2007;

- $\quad$ The develop the three cycle of study based on the National Qualification Framework (NQF);(E. Olldashi \& E. Koka, 2014)

Despite an attempt to understand, adapt the changes that had happened in the field of higher education in relation to the social dimension, the law of higher education nr. 9741 refers only to the economic support for students through scholarships in Article no 57, other support is not mentioned and they are placed under the definitions the Council of Ministers.

Meanwhile the two elements that are part of the social dimension, opportunities, social conditions the ( balance between work and study ) which directly affect the participation and success in higher education are not developed in the law or in the reform of higher education .

In this context, the state support remains only in special cases, which are specified by the Council of Ministers, this kind of philosophy considers the student as a child where the weight for his education is the burden of the family.

\subsection{How it is perceived the social dimension in the "White Paper" and in the new draft of Higher Education Law?}

After the law of 2007 and updates that it had until 2012, it was necessary to develop a reform that would define new standards in higher education.

According to the commission of higher education and sciences, which was responsible for the designing of the 
white paper, until then there was no clear policy development and no philosophy of high education. The system was characterized by a large number of legal regulations without vision and often-uncontrolled implementation (the reform of higher education and scientific research, January - April 2014)

It was no study conducted on a national level as an analysis of the real possibilities that lead to employment and development of the country. There was no orientation of higher education towards meeting the market needs.

Private system of Higher Education appeared fragmented, with private institutions which had no profile of its own, with many study programs of all levels, but holding too few numbers of students in relation to the total number. Today in Albania there are, 44 private HEls hold only $20 \%$ of the total number of students in the whole country.

The quality of HEls and study programs in the public system was not tested through the process of evaluation and accreditation, and the system affecting the private HEls as well.

The higher education today has a high diversity in the academic offer, which is expanding indiscriminate and unjustified policy and planning for the size, population, and the Albanian market demand.

Despite massive policies (in practice) for the qualification of the academic staff, yet many university facilities did not meet the current standards of qualification, also due to their ongoing expansion.

Scientific Research, as a key component to the higher education institutions, especially for those with a "university" status, is very low, compared to European universities. While this problem is more evident in universities that operate outside of Tirana and most private HEls.

Albanian institutions of higher education have a lack of visibility and limited international and European dimension; they are almost entirely the domestic. This is evidenced by the unsatisfactory involvement in inter-institutional cooperation with the long-term impact and visibility, through the limited number of common study programs, very few exchanges of students (while the mobility of academic staff, have little effect on institutional development).

Under this critical approach was drafted the white paper and on its philosophy was drafted the the law on higher education in Albania, which is expected to enter into force in September 2015.

Despite the critical position on the quality of higher education which was introduced, in relation to the social dimension the new proposed draft of higher education has a lot to improve.

However the achievements of the new draft of higher education are:

- there is a clearer definition in Article no. 98, for students services as a result of having student status;

- it offers a detail definition for teaching grant in the Article no 110 , where it is specified in paragraph no 3 that the state offers a. scholarships for excellent students ; b. scholarships for students in programs of study that constitute a national priority ; c. scholarships for students belonging to disadvantaged social strata;

- For the first time the draft provides the introduction of the system of student loans in the article no.112, in order to support student cost.

\section{Student reactions to the reform and the draft of the Higher Education Law}

As never before in Albanian Higher Education it is an organized reaction to the reform, the feedback emanate from the academic staff, universities, but the stronger reaction is the student's reaction.

Analyzing the income going to the higher education and universities in 2015 in relation to GDP, it is less money and this is the third year in row that the budget that is allocated to higher education is reduced.

In this context, the decreased funds in higher education mean that rates will continue to rise. For the academic year 2015-2016 it is expected that the rates will rise to cover the lack of state funds , a minimum of $15-20 \%$ and possibly higher if the government will aim to increase student participation in the cost of higher education studies by over $50 \%$,

Considering the above approach Arlin Qorri (part of the academic staff at Tirana University) and activists of the movement "For the university" thinks that, university will be constrained to reveal itself more and more income thus the professor salary will depend on student fees.

So, instead we have a faculty -student interaction in order to pressure the government to increase the funding of public universities, we will have a fight for survival between teachers and students. Fees will grow even faster from what they raise these years. According to an account of incomplete data emanating from the government, it turns out that every year the fees are expected to grow on average by over 100 Euros .

Consequently, according to Qorri there will be more and more poor students who will be forced to abandonee their studies, because of the inability to cope with their education, and we will have more public university which will me poorer. 


\subsection{What will be the future?}

According to Lorenza Antonucci the condition of young people in higher education in 2020 will be highly dependent on the impact of the last reforms that countries will undertake. In a climate characterized by increasingly residual forms of student support, decreased public spending, higher competition and funding for a few excellent students, the experience of higher education risks becoming increasingly differentiated. Entering into higher education will not only be more difficult, but will also have different implications for young people, depending on their socio-economic backgrounds and their capacity to afford higher education and face the living costs associated with this experience.

While having in mind that the Albanian Higher Education is far from being competitive in order to attract international students who bring more "Money" to higher education, makes us think that, the varieties of the student experience will be multiplied.

Citing Antonucci, about the future of students she concludes that young people are going to have more debts, more loans and increasingly rely on family sources to face the costs of higher education. Debt influences the postuniversity lives of young people and potentially future labor-market choices. Young people are also likely to participate more in the labor market during their studies in order to face the increasing costs; with the scarcity of jobs available to graduates, young people in higher education will risk being stuck in low-skilled jobs.

\section{Recommendations instead of conclusions}

The social dimension according to Orr has a unique character as a policy issue, because it is very general and nonspecific until it is related to a specific context. For this reason, it might be surprising to see it given such attention on the European level.

However, it should remain in the attention of countries that have included the social dimension to give more importance and space in the higher education policy.

In the case of Albania, what I would recommend is a. first to undertake a comprehensive study in which conditions of Albanian students in relation to the funding , support, work are explained likein the questionnaire of EUROSTUDENT $(1,2 \ldots .6)$ which helps countries to have a clearer picture of student life and conditions: $b$. to have more transparent policies for supporting the students $c$. to have a monitoring system for the implementation of policies that promote the social dimension .

\section{References}

http://pjp-eu.coe.int/documents/1017981/7110731/Antonucci.pdf/9025cb4c-9dc1-45c8-8b84-dd7c24643898 (accessed for the last time on the $20^{\text {th }}$ June 2015 ) -

http://www.academicus.edu.al/nr9/Academicus-MMXIV-9-107-119.pdf (accessed for the last time on the 15th June 2015)

http://www.arsimi.info/2014/10/studentet-ne-protesta.html ( (accessed for the last time on the 28 th June 2015)

http://www.ehea.info/Uploads/Good-practices\%20in\%20SD_Croatia.pdf ( accesed for the last time on the 20th June 2015)

http://www.pl4sd.eu/index.php/the-social-dimension/what-is-the-social-dimension (accessed for the last time on the 15th June 20015)

Law for Higher Education and Science in the Republic of Albania, no. 9741, date 21.05.2007

The working paper of Higher Education Law and Scientific Research in the Republic of Albania, in progress

White paper for the reform in Higher education and scientific research in Albania, January - April 2014 